\begin{tabular}{|c|c|c|}
\hline \multirow{3}{*}{$\begin{array}{r}\text { Case Reports in } \\
\text { Gastroenterology }\end{array}$} & \multirow{2}{*}{\multicolumn{2}{|c|}{ Case Rep Gastroenterol 2016;10:553-559 }} \\
\hline & & \\
\hline & $\begin{array}{l}\text { DOI: 10.1159/000450543 } \\
\text { Publisnea ontune. Uctover 18, } 2016\end{array}$ & $\begin{array}{l}\text { (c) } 2016 \text { The Author(s) } \\
\text { Published by S. Karger AG, Basel } \\
\text { www.karger.com/crg }\end{array}$ \\
\hline & $\begin{array}{l}\text { This article is licensed under the } \\
\text { International License (CC BY-NC) } \\
\text { Usage and distribution for commerci }\end{array}$ & $\begin{array}{l}\text { nons Attribution-NonCommercial } 4.0 \\
\text { ger.com/Services/OpenAccessLicense). } \\
\text { juires written permission. }\end{array}$ \\
\hline
\end{tabular}

\title{
Severe de novo Hepatitis B Recovered from Late-Onset Liver Insufficiency with Prolonged Ascites and Hypoalbuminemia due to Hepatitis B Virus Genotype Bj with Precore Mutation
}

\author{
Akira Sato $^{a}$ Toshiya Ishii $^{a} \quad$ Fumiaki Sano $^{b}$ Takayuki Yamada $^{c}$ \\ Hideaki Takahashi $^{a}$ Nobuyuki Matsumoto ${ }^{d}$ \\ ${ }^{a}$ Division of Gastroenterology, Department of Internal Medicine, St. Marianna University \\ School of Medicine Yokohama City Seibu Hospital, Yokohama, Japan; ${ }^{b}$ Division of \\ Hematology and Oncology, Department of Internal Medicine, St. Marianna University \\ School of Medicine Yokohama City Seibu Hospital, Yokohama, Japan; 'Department of \\ Radiology, St. Marianna University School of Medicine Yokohama City Seibu Hospital \\ Yokohama, Japan; ${ }^{d}$ Division of Gastroenterology and Hepatology, Department of Internal \\ Medicine, St. Marianna University School of Medicine, Kawasaki, Japan
}

\section{Keywords}

De novo hepatitis B · Reactivation · Precore mutant · Immunosuppression · Entecavir

\begin{abstract}
De novo hepatitis $B$ is associated with a high risk of hepatic failure often resulting in fatal fulminant hepatitis even when nucleotide analogues are administered. A 77-year-old female developed de novo hepatitis B after R-CHOP (rituximab, cyclophosphamide, doxorubicin, vincristine, and prednisolone) treatment for diffuse large B-cell lymphoma. Hepatitis B virus (HBV) isolated from the patient was of genotype Bj, with a precore mutation (G1896A) exhibiting an extremely high viral load at the onset of hepatitis. She showed markedly high levels of transaminase with mild jaundice on admission and rapid decrease of prothrombin activity
\end{abstract}


after admission. Although acute liver failure was averted by the administration of entecavir and corticosteroid pulse therapy, liver volume decreased to $860 \mathrm{ml}$, and marked hypoalbuminemia accompanying massive ascites occurred 2 months after the onset of hepatitis and persisted for 3 months with high levels of HBV DNA and mild abnormal alanine aminotransferase levels. Frequent infusions of albumin solution, nutrition support, and alleviation therapy showed limited effect. However, overall improvement along with HBV DNA reduction was observed after increasing the dose of entecavir and completion of prednisolone that was administered with a minimum dose for adrenal insufficiency. An immediate and sufficient suppression of virus replication with potent antiviral therapy is critical, particularly in patients infected with HBV precore mutation (G1896A) and/or Bj genotype, which may have a high viral replication and direct hepatocellular damage.

(C) 2016 The Author(s)

Published by S. Karger AG, Basel

\section{Introduction}

Reactivation of hepatitis B virus (HBV) replication is a well-recognized complication in patients with chronic HBV infection receiving cytotoxic or immunosuppressive therapy. It is characterized by the sudden increase or reappearance of HBV DNA in the serum of a patient with prior evidence of resolved or inactive HBV infection [1]. It is more frequent in patients with chronic HBV infection than in patients who have resolved the infection, as indicated by the presence of anti-HBc and/or anti-HBs, known as 'de novo hepatitis B' [2]. However, recently, the incidence of de novo hepatitis B is notably increasing with the introduction of molecular targeted drugs [3] and is of major concern because of its increasing morbidity and higher mortality rate $[4,5]$. Although guidelines recommend the administration of a nucleos(t)ide analogue (NA) for the prophylaxis of HBV reactivation [6, 7], management after HBV reactivation is not well described because the clinical course varies. However, the prognosis of patients who develop hepatitis after chemotherapy including rituximab has shown to have high mortality, even when NA was administered [8]; recently, the fulminant outcome of HBV reactivation associated with genotype Bj with precore mutation (PCm) (G1896A) has been reported [9].

We describe a case of de novo hepatitis B caused by genotype Bj with PCm after R-CHOP [rituximab, cyclophosphamide, doxorubicin, vincristine, and prednisolone (PSL)] treatment with late occurrence hepatic insufficiency showing prolonged ascites and hypoalbuminemia, and overall improvement along with reduction of HBV replication, suggesting the importance of immediate and sufficient viral suppression for the treatment of the disease.

\section{Case Report}

A 77-year-old female was treated with six courses of R-CHOP for stage 1a diffuse large B-cell lymphoma (DLBCL). Prior to chemotherapy, the patient had no history of blood transfusions or surgery, except for tonsillectomy due to DLBCL. The patient had hypertension and hyperlipidemia, which were treated with amlodipine besylate, candesartan cilexetil, hydrochlorothiazide, and pravastatin sodium. Before chemotherapy, her serum was negative for hepatitis B surface antigen (HBsAg) and she had a normal liver function test with a Fibrosis4 score of 1.59, but anti-HBc and anti-HBs were not evaluated. Four weeks after the completion of R-CHOP, she presented to our hospital with general fatigue and a loss of appetite. The patient weighed $64.0 \mathrm{~kg}$, and her height was $148 \mathrm{~cm}$. Mild jaundice was noted on physical 


\section{Case Reports in \\ Gastroenterology}

Case Rep Gastroenterol 2016;10:553-559

DOI: $10.1159 / 000450543$

(c) 2016 The Author(s). Published by S. Karger AG, Basel www.karger.com/crg

Sato et al: Severe de novo Hepatitis B Recovered from Late-Onset Liver Insufficiency with Prolonged Ascites and Hypoalbuminemia due to HBV Genotype Bj with PCm

examination, but an abdominal computed tomography (CT) revealed no abnormal findings in the hepatobiliary system. Laboratory examination revealed marked hepatocellular injury (table 1). HBsAg changed to positive and HBV DNA load exhibited $\geq 9.0 \log$ copies/ml; therefore, the patient was diagnosed with de novo hepatitis B. The patient was immediately admitted, and entecavir (ETV) was administered at a dose of $1.0 \mathrm{mg}$ on day 1 followed by 0.5 $\mathrm{mg} /$ day. On day 3 , her serum transaminase levels appeared almost unchanged, total bilirubin slightly increased to $4.3 \mathrm{mg} / \mathrm{dl}$, and prothrombin (PT) activity decreased from 80 to $71 \%$ in 1 day. Therefore, we commenced corticosteroid (CS) pulse therapy as follows: 1,000 $\mathrm{mg} /$ day of methylprednisolone (MPSL) was administered for 3 days and was reduced to half doses every 2 days. After the administration of $125 \mathrm{mg} /$ day of MPSL for 2 days, $60 \mathrm{mg} /$ day of PSL was administered for 4 days and then reduced by 5 mg every 5 days. PT activity recovered to $>80 \%$ and alanine aminotransferase (ALT) levels decreased to $980 \mathrm{IU} / \mathrm{l}$ on day 5; however, serum albumin levels decreased to $2.8 \mathrm{~g} / \mathrm{dl}$ (fig. 1). HBV DNA load amounted to 8.8 $\log$ copies/ml on day 7 and the decrease in load was very slow, amounting to 8.5 log copies/ml on day 14 and $7.9 \log$ copies/ml on day 29. Hepatic volume measured by CT decreased from $1,360 \mathrm{ml}$ on day 1 , to $1,100 \mathrm{ml}$ on day 18 , and to $990 \mathrm{ml}$ on day 41 . On day 46, HBV DNA remained at $7.6 \mathrm{log}$ copies $/ \mathrm{ml}$ and serum albumin decreased to $2.5 \mathrm{~g} / \mathrm{dl}$, although the PT activity was $100 \%$. We initiated the administration of branched chain amino acid (BCAA) granules (1.2 g/day), and $100 \mathrm{ml}$ of $25 \%$ albumin solution was administered. However, the increase in serum albumin levels was only minor. On day 60, with ALT levels decreasing to $<100 \mathrm{IU} / \mathrm{l}$, PSL was reduced to $5 \mathrm{mg} /$ day, but the patient complained of a sense of fullness. A CT of the abdomen revealed marked ascites and a decreased hepatic volume of $860 \mathrm{ml}$ (fig. 2). Administration of BCAA was changed from granules to a BCAA-enriched nutrient mixture, containing $1.7 \mathrm{~g}$ of BCAA and $40.5 \mathrm{~g}$ of protein/day, and the administration of diuretics was started. However, the patient required frequent infusions of albumin solution to maintain serum albumin levels $>2.5 \mathrm{~g} / \mathrm{dl}$. On day 68, PSL dosage was reduced to 2.5 $\mathrm{mg} /$ day, and the administration of ursodeoxycholic acid (UDCA) and intravenous glycyrrhizin was initiated. However, the patient complained of weakness and anorexia 3 days later. Her urine 17-ketogenic steroids showed markedly low levels $(0.8 \mathrm{mg} /$ day; standard value: $3.55-11.2 \mathrm{mg} /$ day), indicating adrenal insufficiency. PSL dosage was increased to 15 $\mathrm{mg} /$ day, leading to a gradual alleviation of weakness and anorexia, and PSL was then reduced very slowly with a maintenance dosage of $5 \mathrm{mg} /$ day since day 102. HBV DNA decreased to $5.4 \log$ copies/ml on day 116, after which the decrease paused and the levels remained unchanged after 50 days, although ETV-resistant substitutions were not detected. However, serum albumin levels barely increased to $3.1 \mathrm{~g} / \mathrm{dl}$, hepatic volume recovered to $1,270 \mathrm{ml}$, ascites disappeared on day 114, and PSL was decreased gradually from $5 \mathrm{mg} /$ day and discontinued after the administration of $2 \mathrm{mg} /$ day during the last 2 weeks. Eight days after the cessation of PSL, ALT levels, having fluctuated within $55 \mathrm{IU} / \mathrm{l}$ for 60 days prior to this, now increased to $116 \mathrm{IU} / \mathrm{l}$, and the serum albumin levels again decreased to $2.7 \mathrm{~g} / \mathrm{dl}$. We increased the dosage of ETV from 0.5 to $1.0 \mathrm{mg} /$ day. ALT further increased to $260 \mathrm{IU} / \mathrm{l}$, and the serum albumin levels decreased to $2.5 \mathrm{~g} / \mathrm{dl}$, resulting in pleural effusion. However, HBV DNA decreased from 5.5 to $4.5 \mathrm{log}$ copies/ml, ALT decreased dramatically to $36 \mathrm{IU} / \mathrm{l}$ 2 weeks later, and serum albumin levels increased to $3.1 \mathrm{~g} / \mathrm{dl} 3$ weeks later. UDCA and glycyrrhizin were discontinued on day 186 with the stabilization of ALT levels <30 IU/l. Pleural effusion disappeared on day 214 , and the patient was discharged. 


\section{Case Reports in Gastroenterology}

Case Rep Gastroenterol 2016;10:553-559

DOI: $10.1159 / 000450543$

C 2016 The Author(s). Published by S. Karger AG, Basel www.karger.com/crg

Sato et al:: Severe de novo Hepatitis B Recovered from Late-Onset Liver Insufficiency with Prolonged Ascites and Hypoalbuminemia due to HBV Genotype Bj with PCm

\section{Discussion}

We present a patient with severe de novo hepatitis B recovered from liver insufficiency. This patient indicated the importance of immediate and sufficient suppression of virus replication of the disease, and suggested direct cytopathic effect of HBV under immune suppressive conditions.

De novo hepatitis B is associated with a high risk of hepatic failure, often resulting in a fatal fulminant hepatitis despite the administration of NA $[5,10]$. According to a Japanese nationwide survey, all patients with acute liver failure associated with de novo hepatitis B had either a subacute type of fulminant hepatitis or late-onset hepatic failure [11], indicating that the clinical signs of liver failure may appear at a later stage after the onset of the disease. This patient developed neither marked coagulopathy nor encephalopathy; however, she showed a continuous decrease of hepatic volume and late occurrence of ascites, both of which are considered to be poor prognostic signs in patients with acute liver failure $[12,13]$. Furthermore, a decline of the liver volume below $1,000 \mathrm{ml}$ is reported to be less recoverable by medical management [14]. Although the patient did not develop acute liver failure, she suffered from prolonged ascites. The hepatic injury during acute and chronic hepatitis B has been considered to be caused by the host's immune response against infected hepatocytes [15]. Therefore, it is reasonable to treat severe hepatitis B with CS to suppress immune response [16]. Fujiwara et al. [17] reported that among patients with a severe acute exacerbation of chronic HBV, which is known to sometimes progress to hepatic failure, treated with CS in combination with NA, a decline of HBV DNA during the first 2 and 4 weeks was significant in recovered patients (mean: 2.0 and 3.0 log copies $/ \mathrm{ml}$, respectively). In this patient, a decrease in ALT was achieved by PSL with ETV therapy. However, the HBV DNA level before treatment was extremely high $(\geq 9.0 \mathrm{log} / \mathrm{ml})$ and the decline was slow, showing 7.9 log copies/ml on day 29 , and had stopped at the level of $>5.0 \mathrm{log}$ copies $/ \mathrm{ml}$ for 50 days although no drug resistance was detected. The ascites with lower serum albumin levels with mild ALT abnormality persisted until 5 months after the onset of the disease. These concurrently improved after the discontinuation of PSL and increasing ETV from 0.5 to $1.0 \mathrm{mg} /$ day. Retrospectively, this change appeared essential due to a reduction in virus replication by immune restoration and by the dose increasing effect of ETV [18], and indicates the importance of sufficient suppression of virus replication.

At the same time, this clinical course suggests a direct cytopathic effect of HBV. Recently, several data supporting the cytopathic effect of HBV replication have been reported [19], and similar correlation between serum albumin levels and HBV DNA levels but not ALT levels was also reported [20]. Foo et al. [21] demonstrated accumulation of HBV large surface protein-induced hepatocyte apoptosis in cultured hepatoma cells, and Meuleman et al. [22] reported a direct cytopathic effect in hepatocytes that contained extremely high amounts of HBV genomes and proteins using severe combined immune deficient mice harboring human liver cells. Clinically, fibrosing cholestatic hepatitis (FCH), which is characterized by rapid and progressive liver dysfunction with increased viral replication and high intrahepatic expression of virus proteins, occurs in immunosuppressed patients and is considered to be a cytopathic form of the virus [23]. Although our patient was not cholestatic, functional failure with high viral replication and modest increase of transaminases is similar to the clinical features of FCH. Furthermore, HBV PCm has been reported to be associated with patients with $\mathrm{FCH}$ [24], and HBV Bj genotype with $\mathrm{PCm}$, which was present in this patient and in the case of Sugauchi et al. [9], is reported to have a high viral replication and induces a direct cytopathic effect in immune suppressive conditions [25]. In this patient, ALT flare occurred 
after discontinuation of PSL, indicating the recovery from immune suppression state. Thus, we considered that liver injury in acute phase would be mainly caused by enhanced immune response; however, in later stages it would be due to direct hepatocellular damage of the virus with high replication.

In conclusion, the immediate and sufficient suppression of virus replication with potent antiviral treatment as well as control of enhanced host immune response is important in severe de novo hepatitis B, particularly in patients infected with HBV PCm and/or Bj genotype, who may have associated high viral replication and direct hepatocellular damage.

\section{Statement of Ethics}

Informed consent was obtained from the patient prior to the publication of this study.

\section{Disclosure Statement}

The authors have no competing interest to declare.

\section{References}

1 Hoofnagle JH: Reactivation of hepatitis B. Hepatology 2009;49:S156-S165.

-2 Lok AS, Liang RH, Chiu EK, Wong KL, Chan TK, Todd D: Reactivation of hepatitis B virus replication in patients receiving cytotoxc therapy. Report of a prospective study. Gastroenterology 1991;100:182188.

-3 Yeo W, Chan TC, Leung NW, Lam WY, Mo FK, Chu MT, Chan HL, Hui EP, Lei KI, Mok TS, Chan PK: Hepatitis B virus reactivation in lymphoma patients with prior resolved hepatitis B undergoing anticancer therapy with or without rituximab. J Clin Oncol 2009;27:605-611.

4 Hui CK, Cheung WWW, Zhang HY, Au WY, Yueng YH, Leung AY, Leung N, Luk JM, Lie AK, Kwong YL, Liang R, Lau GK: Kinetics and risk of de novo hepatitis B infection in HBsAg-negative patients undergoing cytotoxic chemotherapy. Gastroenterology 2006;131:59-68.

-5 Umemura T, Tanaka E, Kiyosawa K, Kumada H; Japan de novo Hepatitis B Research Group: Mortality secondary to fulminant hepatic failure in patients with prior resolution of hepatitis B virus infection in Japan. Clin Infect Dis 2008;47:e52-e56.

6 Lok ASF, McMahon BJ: AASLD practice guidelines: chronic hepatitis B: update 2009. Hepatology 2009;50:1-36.

7 European Association for the Study of the Liver: EASL clinical practice guidelines: Management of chronic hepatitis B virus infection. J Hepatol 2012;57:167-185.

8 Pei SN, Chen CH, Lee CM, Wang MC, Ma MC, Hu TH, Kuo CY: Reactivation of hepatitis B virus following rituximab-based regimens: a serious complication in both HBsAg-positive and HBsAg-negative patients. Ann Hematol 2010;89:255-262.

-9 Sugauchi F, Tanaka Y, Kusumoto S, Matsuura K, Sugiyama M, Kurbanov F, Ueda R, Mizokami M: Virological and clinical characteristics on reactivation of occult hepatitis B in patients with hematological malignancy. J Med Virol 2011;83:412-418.

10 Oketani M, Ido A, Uto H, Tsubouchi H: Prevention of hepatitis B virus reactivation in patients receiving immunosuppressive therapy or chemotherapy. Hepatol Res 2012;42:627-636.

11 Oketani M, Ido A, Nakayama N, Takikawa Y, Naiki T, Yamagishi Y, Ichida T, Mochida S, Onishi S, Tsubouchi H; Intractable Hepato-Biliary Diseases Study Group of Japan: Etiology and prognosis of fulminant hepatitis and late-onset hepatic failure in Japan: Summary of the annual nationwide survey between 2004 and 2009. Hepatol Res 2013;43:97-105.

12 Sekiyama K, Yoshiba M, Inoue K Sugata F: Prognostic value of hepatic volumetry in fulminant hepatic failure. Dig Dis Sci 1994;39:240-244.

-13 Itai Y, Sekiyama K, Ahmadi T, Obuchi M, Yoshiba M: Fulminant hepatic failure: Observation of serial CT. Radiology 1997;202:379-382.

14 Shakil AO, Jones BC, Lee RG, Federle MP, Fung JJ, Rakela J: Prognostic value of abdominal CT scanning and hepatic histopathology in patients with acute liver failure. Dig Dis Sci 2000;45:334-339. 


\section{Case Reports in \\ Gastroenterology}

\begin{tabular}{l|l}
\hline Case Rep Gastroenterol 2016;10:553-559 \\
\hline DOI: 10.1159/000450543 & $\begin{array}{l}\text { @ 2016 The Author(s). Published by S. Karger AG, Basel } \\
\text { www.karger.com/crg }\end{array}$ \\
\hline
\end{tabular}

Sato et al.: Severe de novo Hepatitis B Recovered from Late-Onset Liver Insufficiency with Prolonged Ascites and Hypoalbuminemia due to HBV Genotype Bj with PCm

15 Chisari FV: Hepatitis B virus immunopathogenesis. Annu Rev Immunol 1995;13:29-60.

16 He B, Zhang Y, Lü MH, Cao YL, Fan YH, Deng JQ, Yang SM: Glucocorticoids can increase the survival rate of patients with severe viral hepatitis B: a meta-analysis. Eur J Gastroenterol Hepatol 2013;25:926-934.

-17 Fujiwara K, Yasui S, Okitsu K, Yonemitsu Y, Oda S, Yokosuka O: The requirement for a sufficient period of treatment in combination with nucleoside analogue for severe acute exacerbation of chronic hepatitis B. J Gastroenterol 2010;45:1255-1262.

-18 Erturk A, Akdogan RA, Parlak E, Cure E, Cumhur Cure M, Ozturk C: Is increasing the dose of entecavir effective in partial virological responders? Drug Des Devl Ther 2014;29:621-625.

19 Zhang YY, Kq H: Rethinking the pathogenesis of hepatitis b virus (HBV) infection. J Med Virol 2015;87:1989-1999.

20 Nakamuta M, Kotoh K, Enjoji M, Kajiwara E, Shimono J, Masumoto A, Maruyama T, Furusyo N, Nomura H, Sakai H, Takahashi K, Azuma K, Shimoda S, Tanabe Y, Hayashi J: Effects of lamivudine on serum albumin levels correlate with pretreatment HBV-DNA levels in cirrhotic patients. Comp Hepatol 2007;6:3.

-21 Foo NC, Ahn BY, Ma X, Hyun W, Yen TS: Cellular vacuolization and apoptosis induced by hepatitis B virus large surface protein. Hepatology 2002;36:1400-1407.

22 Meuleman P, Libbrecht L, Wieland S, De Vos R, Habib N, Kramvis A, Roskams T, Leroux-Roels G: Immune suppression uncovers endogenous cytopathic effects of the hepatitis B virus. J Virol 2006;80:2797-2807.

23 Xiao SY, Lu L, Wang HL: Fibrosing cholestatic hepatitis: clinicopathologic spectrum, diagnosis and pathogenesis. Int J Clin Exp Pathol 2008;1:396-402.

24 Angus PW, Locarnini SA, McCaughan GW, Jones RM, McMillan JS, Bowden DS: Hepatitis B virus precore mutant infection is associated with severe recurrent disease after liver transplantation. Hepatology 1995;21:14-18.

25 Sugiyma M, Tanaka Y, Kurbanov F, Maruyama I, Shimada T, Takahashi S, Shirai T, Hino K, Sakaida I, Mizokami M: Direct cytopathic effects of particular hepatitis B virus genotypes in severe combined immunodeficiency transgenic with urokinase-type plasminogen activator mouse with human hepatocytes. Gastroenterology 2009;136:652-662.

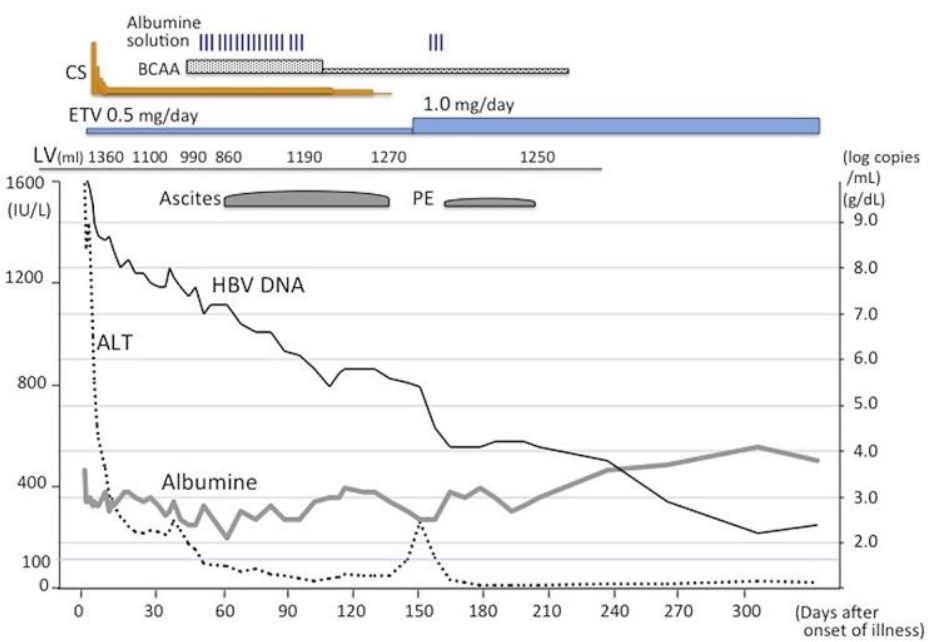

Fig. 1. Clinical course of the patient. BCAA = Branched chain amino acid; $\mathrm{CS}=$ corticosteroid; $\mathrm{ETV}=$ entecavir; $\mathrm{LV}=$ liver volume; $\mathrm{ALT}=$ alanine aminotransferase; $\mathrm{PE}=$ pleural effusion. 


\section{Case Reports in Gastroenterology}

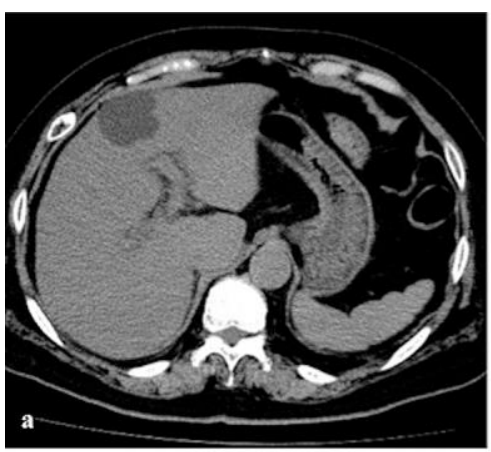

\begin{tabular}{l|l}
\hline Case Rep Gastroenterol 2016;10:553-559 \\
\hline DOI: 10.1159/000450543 & $\begin{array}{l}\text { C 2 2016 The Author(s). Published by S. Karger AG, Basel } \\
\text { www.karger.com/crg }\end{array}$ \\
\hline
\end{tabular}

Sato et al: Severe de novo Hepatitis B Recovered from Late-Onset Liver Insufficiency with Prolonged Ascites and Hypoalbuminemia due to HBV Genotype Bj with PCm
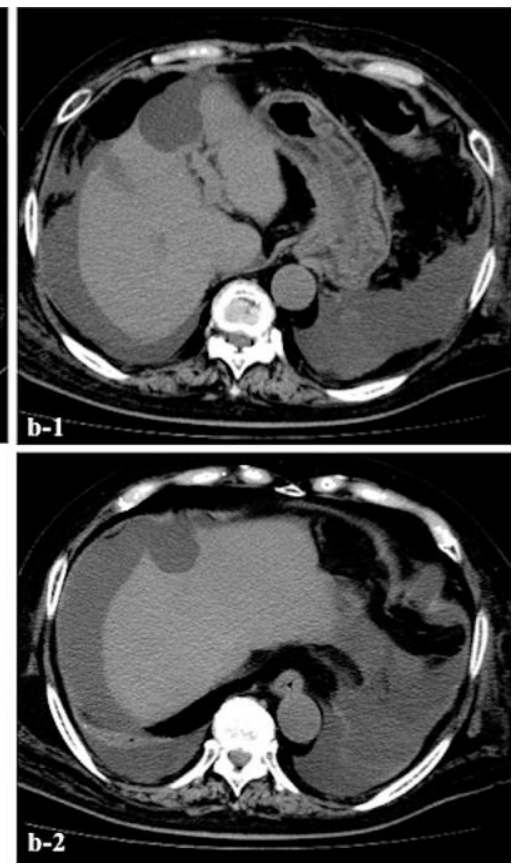

Fig. 2. Serial CT scans of the patient. a Initial CT scan obtained at disease onset showed neither ascites nor atrophy of the liver. b CT scan obtained on day 68 of the disease showed decrease in size of the liver (b-1), and massive ascites with moderate pleural effusion (b-2).

Table 1. Laboratory findings on admission

\begin{tabular}{llllll}
\hline Item & Value & Item & Value & Item & Value \\
\hline WBC & $2,200 / \mu \mathrm{l}$ & $\gamma$-GTP & $214 \mathrm{IU} / \mathrm{l}$ & Anti-HAV IgM & - \\
$\mathrm{Hb}$ & $14.4 \mathrm{~g} / \mathrm{dl}$ & $\mathrm{TP}$ & $6.2 \mathrm{~g} / \mathrm{dl}$ & $\mathrm{HCV}$ RNA & - \\
$\mathrm{Hct}$ & $44.1 \%$ & $\mathrm{Alb}$ & $3.6 \mathrm{~g} / \mathrm{dl}$ & $\mathrm{HBsAg}$ & $+(>2,000)(\mathrm{S} / \mathrm{CO})$ \\
Platelets & $14.1 \times 10^{4} / \mu \mathrm{l}$ & $\mathrm{TC}$ & $176 \mathrm{mg} / \mathrm{dl}$ & Anti-HBs & $-(<\times 8)(\mathrm{PHA})$ \\
$\mathrm{PT}$ & $79.0 \%[80.0,71.0]$ & $\mathrm{UA}$ & $4.4 \mathrm{mg} / \mathrm{dl}$ & Anti-HBc & $+(10.1)(\mathrm{S} / \mathrm{CO})$ \\
PT-INR & $1.11[1.11,1.18]$ & $\mathrm{UN}$ & $13.4 \mathrm{mg} / \mathrm{dl}$ & Anti-HBc IgM & $-(0.34)(\mathrm{S} / \mathrm{CO})$ \\
T-BIL & $3.9 \mathrm{mg} / \mathrm{dl}[3.3,4.3]$ & $\mathrm{Cre}$ & $0.88 \mathrm{mg} / \mathrm{dl}$ & $\mathrm{HBeAg}$ & $-(0.47)(\mathrm{S} / \mathrm{CO})$ \\
$\mathrm{D}-\mathrm{BIL}$ & $2.5 \mathrm{mg} / \mathrm{dl}[2.1,2.9]$ & Glucose & $93 \mathrm{mg} / \mathrm{dl}$ & Anti-HBe & $-(19.6)(\mathrm{S} / \mathrm{CO})$ \\
AST & $2,771 \mathrm{IU} / \mathrm{l}$ & AFP & $7.5 \mathrm{ng} / \mathrm{ml}$ & HBV DNA & $\geq 9.0 \log \operatorname{copies} / \mathrm{ml}$ \\
ALT & $1,589 \mathrm{IU} / \mathrm{l}$ & & & HBV genotype & $\mathrm{Bj}$ \\
LDH & $1,077 \mathrm{IU} / \mathrm{l}$ & ANA & - & Precore & Mutant $100 \%$ \\
ALP & $566 \mathrm{IU} / \mathrm{l}$ & & & Core promotor & Wild \\
\hline
\end{tabular}

Values of days 2 and 3 are shown in square brackets. WBC = White blood cell count; Hb = hemoglobin; Hct = hematocrit; PT = prothrombin time; PT-INR = PT international normalized ratio; T-BIL = total bilirubin; D-BIL = direct bilirubin; AST = aspartate aminotransferase; $\mathrm{LDH}=$ lactate dehydrogenase; ALP = alkaline phosphatase; $\gamma$-GTP $=\gamma$-glutamyltransferase; TP $=$ total protein; Alb = albumin; TC = total cholesterol; UA = uric acid; UN = urea nitrogen; Cre = creatinine; AFP = $\alpha$-fetoprotein; ANA = anti-nuclear antibody; HAV = hepatitis A virus; IgM = immunoglobulin M; HCV = hepatitis C virus; HBsAg = hepatitis B surface antigen; $\mathrm{HBeAg}=$ hepatitis $\mathrm{B}$ e antigen. 